\title{
Konsep Tourism Area Life Cycle dalam Mengidentifikasi Karakteristik Taman Wisata di Bantaran Sungai Kalimas Surabaya
}

\author{
Galih Alco Pranata dan Hertiari Idajati \\ Departemen Perencanaan Wilayah dan Kota, Fakultas Arsitektur Desain dan Perencanaan, \\ Institut Teknologi Sepuluh Nopember (ITS) \\ e-mail: hertiari_idajati@urplan.its.ac.id
}

\begin{abstract}
Abstrak - Taman wisata di sepanjang kalimas adalah taman yang dibangun untuk memenuhi kebutuhan $30 \%$ ruang terbuka hijau di Surabaya serta merevitalisasi kawasan kalimas yang pernah mengalami degradasi lingkungan. Meski telah dibangun, mayoritas kondisi infrastruktur taman wisata kalimas ditemukan tidak terawat dan rusak yang berpotensi menyebabkan degradasi lingkungan kembali. Untuk mengantisipasi terjadinya degradasi kembali di sungai kalimas, perlu dilakukan identifikasi karakteristik taman wisata kalimas berdasarkan siklus hidup pariwisata. Oleh karena itu, penelitian ini bertujuan untuk mengidentifikasi karakteristik taman wisata di kalimas melalui analisa deskriptif kualitatif yang membandingkan kondisi di lapangan dengan variabel-variabel dan kriteria tahapan berdasarkan siklus hidup pariwisata. Hasil dari penelitian ini menunjukkan bahwa dari segi atraksi rata-rata semua taman wisata telah terbangun atraksi alami dan buatan. Jumlah kunjungan kebanyakan meningkat signifikan namun juga terdapat beberapa taman yang hanya meningkat sedikit. Sarana yang terbangun rata-rata sarana rekreasi dan sanitasi.
\end{abstract}

Kata Kunci-Analisa Deskriptif Kualitatif, Identifikasi Karakteristik, Kalimas Surabaya, Siklus Hidup Pariwisata, Taman Wisata.

\section{PENDAHULUAN}

$\mathrm{P}$ EMBANGUNAN taman kota di Surabaya dilakukan untuk memenuhi kebutuhan ruang terbuka hijau (RTH) sebesar $30 \%$ (20\% publik dan $10 \%$ privat) dari luas kota [1], dimana pengadaan RTH di Kota Surabaya paling sedikit seluas 6.610 hektar atau setara dengan $20 \%$ dari luas Kota Surabaya. Untuk memenuhi kebutuhan RTH kota Surabaya sebesar 30\%, salah satu upaya yang dilakukan oleh Pemerintah Kota Surabaya adalah pembangunan taman kota melalui program revitalisasi di bantaran Sungai Kalimas [2]. Tujuan dilakukannya revitalisasi adalah sebagai upaya penataan serta menvitalkan kembali kawasan Sungai Kalimas agar tidak mengalami degradasi lingkungan kembali. arahan yang dilakukan untuk merevitalisasi Sungai Kalimas diantaranya yakni dengan menciptakan ruang terbuka hijau baru di sepanjang kawasan Sungai Kalimas dan menciptakan kegiatan atraktif secara sosial-ekonomi di badan maupun tepian sungai melalui kegiatan pariwisata [2].

Terdapat 5 taman dari ujung selatan hingga utara Sungai Kalimas yang telah beropreasi sebagai hasil dari program

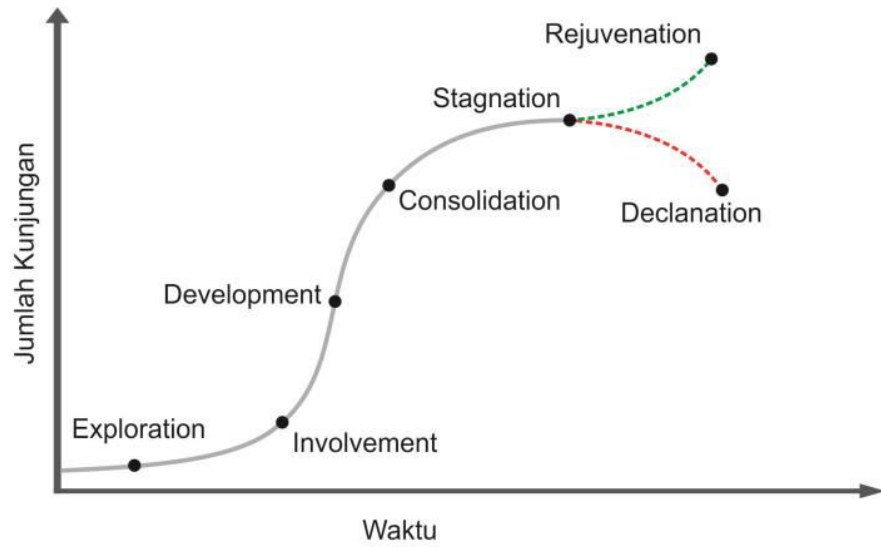

Gambar 1. Tahapan Siklus Hidup Pariwisata.

revitalisasi. Kelima taman tersebut terdiri dari Taman Keputran, Taman BMX \& Skate Arena, Taman Prestasi, Taman Ekspresi, dan Taman Jayengrono [3]. Untuk menghidupkan kegiatan pada kawasan sungai yang terletak di jantung Kota Surabaya ini setiap taman kota memiliki cirikhas dayatarik wisata tersendiri. Dayatarik wisata tersebut diantaranya seperti arena olahraga BMX dan skateboard yang terdapat di Taman BMX \& Skate Arena, aktivitas menunggangi kuda dan menyewa perahu motor di Taman Prestasi, hiasan taman berupa karya seni patung dari material bekas pada Taman Ekspresi, ornamen relief sejarah untuk mengenang pertempuran 10 november 1945 pada Taman Jayengrono, dan lain sebagainya. Selain adanya kegiatan pariwisata sebagai sarana sosial, untuk menunjang kegiatan ekonomi taman-taman tersebut juga dilengkapi kios kios penjualan seperti sentra Pedagang Kaki Lima (PKL).

Meski telah dibangun dengan dayatarik wisata, namun dari segi infrastruktur masih belum bisa melayani pengunjung dengan baik seperti arena playground, toilet, dan kios penjual yang kurang terawat [3]. Seperti pada Taman Keputran yang ditemukan fasilitas taman yang rusak dan kurang diperhatikan seperti tempat sampah yang rusak, serta tiang lampu taman yang patah dan dibiarkan bersandar kepada taman [4].

Butler dalam teori Tourism Area Life Cycle (siklus hidup pariwisata) dijelaskan bahwa salah satu komponen pariwisata yang mempengaruhi performa destinasi pariwisata adalah kondisi sarana dan prasaranya . Kondisi sarana dan prasarana 
Tabel 1.

Variabel Aspek Fungsi Taman

\begin{tabular}{lll}
\hline \hline \multicolumn{1}{c}{ Indikator } & \multicolumn{1}{c}{ Variabel } & \multicolumn{1}{c}{ Definisi Operasional } \\
\hline Fungsi & Vegetasi & Jenis vegetasi yang memberikan efek \\
Lingkungan & Taman & teduh dan keasrian taman \\
Fungsi Sosial & Sarana Sosial & sarana untuk berinteraksi sosial \\
Fungsi Estetika & Penataan & $\begin{array}{l}\text { Perpaduan jenis ragam vegetasi } \\
\text { yang ditanam pada taman }\end{array}$ \\
& Vegetasi & $\begin{array}{l}\text { Cirikhas penataan taman dari taman } \\
\text { lainnya }\end{array}$ \\
\hline \hline
\end{tabular}

Tabel 2.

Variabel Aspek Komponen Pariwsiata

\begin{tabular}{|c|c|c|}
\hline Indikator & Variabel & Definisi Operasional \\
\hline Kelembagaan & Lembaga pengelola & $\begin{array}{l}\text { Pihak yang bertanggung jawab } \\
\text { mengelola taman } \\
\text { Perean pengelola dalam } \\
\text { mengelola taman }\end{array}$ \\
\hline \multirow[t]{3}{*}{$\begin{array}{l}\text { Atraksi dan } \\
\text { obyek daya tarik } \\
\text { wisata }\end{array}$} & $\begin{array}{l}\text { Adanya atraksi } \\
\text { yang dapat dilihat } \\
\text { (something to see) }\end{array}$ & $\begin{array}{l}\text { Pemandangan alami berupa } \\
\text { vegetasi dan penataan estetika } \\
\text { yang dapat dilihat/dinikmati }\end{array}$ \\
\hline & $\begin{array}{l}\text { Atraksi yang dapat } \\
\text { dilakukan } \\
\text { (something tp do) }\end{array}$ & $\begin{array}{l}\text { Aktivitas yang dapat dilakukan } \\
\text { melalui sarana sosial yang } \\
\text { tersedia pada taman }\end{array}$ \\
\hline & $\begin{array}{c}\text { Produk yang dapat } \\
\text { dibeli (something } \\
\text { to buy) }\end{array}$ & $\begin{array}{l}\text { Produk cirikhas pada taman } \\
\text { yang dapat dibeli sebagai } \\
\text { kenang-kenangan }\end{array}$ \\
\hline \multirow[t]{4}{*}{ Fasilitas } & Sarana Rekreasi & $\begin{array}{l}\text { kondisi sarana yang } \\
\text { menunjang atraksi taman } \\
\text { wisata (fungsi lingkungna, } \\
\text { sosial dan fungsi estetika) }\end{array}$ \\
\hline & Sarana Penjualan & $\begin{array}{l}\text { kondisi sarana yang digunakan } \\
\text { untuk menunjang penjualan } \\
\text { produk cirikhas }\end{array}$ \\
\hline & Sarana Sanitasi & kondisi toilet yang tersedia \\
\hline & Sarana Ibadah & kondisi sarana peribatan \\
\hline \multirow[t]{4}{*}{$\begin{array}{l}\text { Infrastruktur } \\
\text { (prasarana) }\end{array}$} & Listrik & $\begin{array}{l}\text { kondisi aliran listrik di wisata } \\
\text { taman kota }\end{array}$ \\
\hline & Air Bersih & $\begin{array}{l}\text { kondisi air bersih di wisata } \\
\text { taman kota }\end{array}$ \\
\hline & Drainase & $\begin{array}{l}\text { kondisi saluran darainase di } \\
\text { wisata taman kota }\end{array}$ \\
\hline & $\begin{array}{l}\text { Sistem } \\
\text { Persampahan }\end{array}$ & $\begin{array}{l}\text { kondisi sistem persampahan di } \\
\text { wisata taman kota }\end{array}$ \\
\hline \multirow[t]{2}{*}{ Aksesibilitas } & Transportasi umum & $\begin{array}{l}\text { kondisi transportasi umum } \\
\text { seperti yang melintas di taman } \\
\text { wisata }\end{array}$ \\
\hline & $\begin{array}{l}\text { Prasarana } \\
\text { transportasi }\end{array}$ & $\begin{array}{l}\text { kondisi tempat parkir taman } \\
\text { wisata }\end{array}$ \\
\hline Promosi & Upaya promosi & $\begin{array}{l}\text { Media yang digunakan untuk } \\
\text { menginfotmasikan taman } \\
\text { wisata } \\
\text { jangkauan penyebaran } \\
\text { informasi }\end{array}$ \\
\hline Pengunjung & $\begin{array}{l}\text { Jumlah } \\
\text { Peningkatan } \\
\text { pengunjung }\end{array}$ & $\begin{array}{l}\text { Trend jumlah kunjungan } \\
\text { dalam } 1 \text { tahun, apakah } \\
\text { meningkat, menurun, atau } \\
\text { stagnan }\end{array}$ \\
\hline
\end{tabular}

pariwisata yang sudah tua dan tidak segera diremajakan dapat menurunkan minat wisatawan untuk berkunjung pada destinasi tersebut. Akibatnya destinasi wisata tersebut akan ditinggalkan

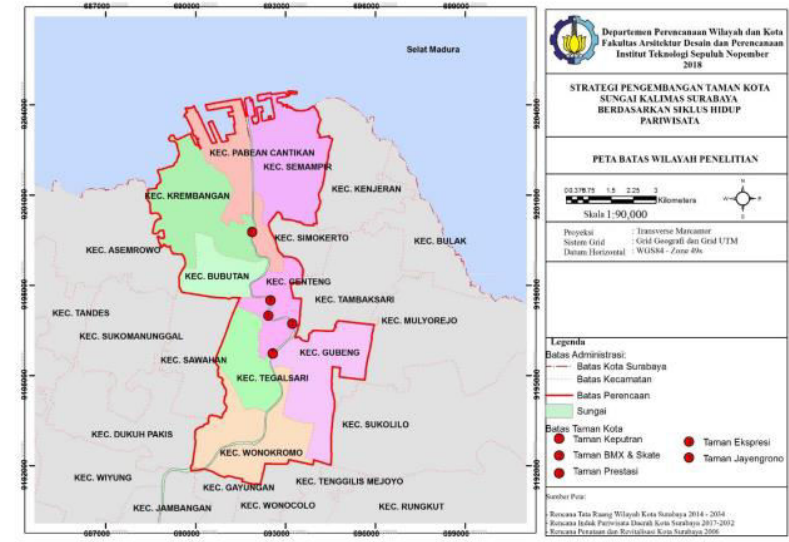

Gambar 2. Peta Lokasi Penelitian.

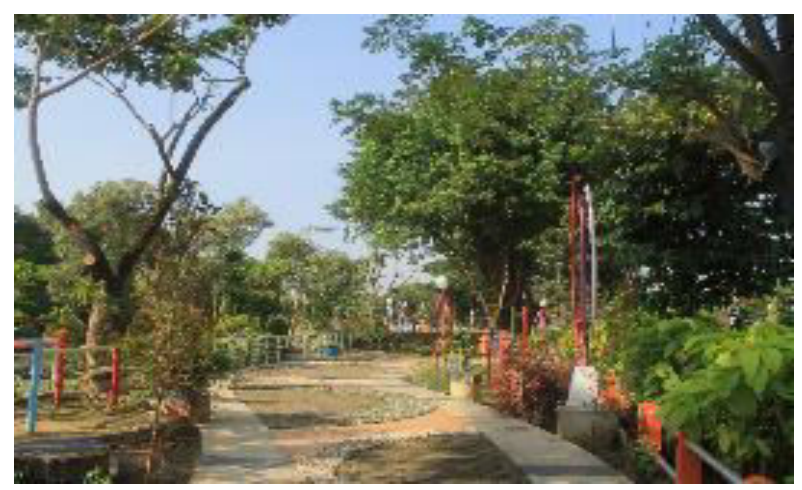

Gambar 3. Taman Wisata Keputran.

oleh wisatawan sehingga tidak terawat dan mengalami degradasi hingga menyebabkan masalah ekonmi, sosial, dan lingkungan. Apabila kondisi infrastruktur pada taman di Sungai Kalimas tetap dibiarkan tidak terwat maka minat wisatawan untuk berkunjung akan berkurang bahkan hingga ditinggalkan. Dampaknya pada destinasi yang ditinggal oleh wisatawan adalah terjadinya degradasi kembali dan menimbulkan masalah ekonomi, sosial, dan lingkungan sehingga tujuan dari dilakukannya revitalisasi tidak tercapai. Oleh karena itu agar terhindar dari permasalahan tersebut penting kirannya dilakukan identifikasi karakteristik siklus hidup pariwisata pada taman kota di sepanjang Sungai Kalimas.

\section{METODE PENELITIAN}

\section{A. Jenis dan Pendekatan Penelitian}

Pendekatan yang digunakan dalam penelitian ini adalah pendekatan rasionalistik [5]. Jenis penelitian dalam penelitian ini adalah deskriptif kualitatif.

\section{B. Variabel Penelitian}

Variabel penelitian yang digunakan untuk mengidentifikasi karakteristik taman wisata di Kalimas adalah variabel dalam Tourism Area Life Cycle (siklus hidup pariwisata). Siklus hidup pariwisata adalah sebuah konsep untuk memprediksi arah kecenderungan pengembangan pariwisata yang bertujuan untuk memahami evolusi dari produk dan destinasi wisata [6]. Evolusi 


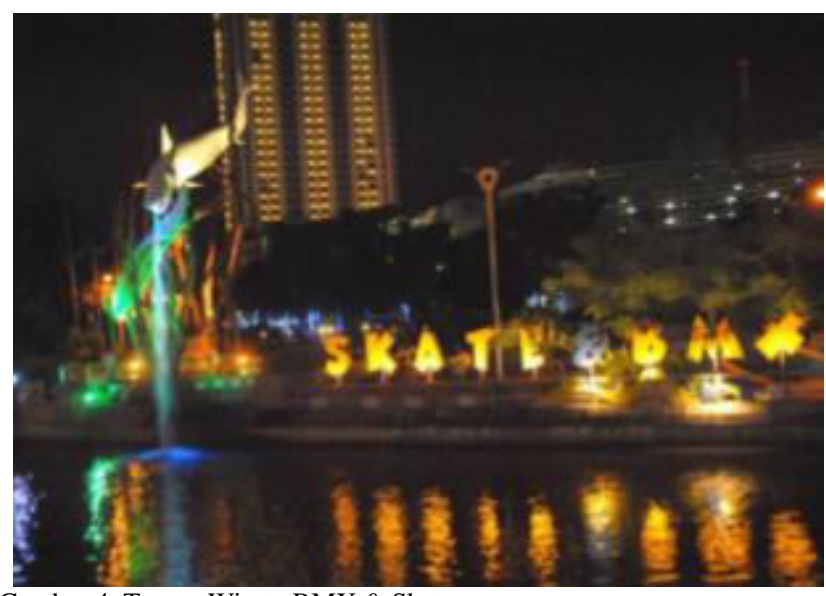

Gambar 4. Taman Wisata BMX \& Skate.

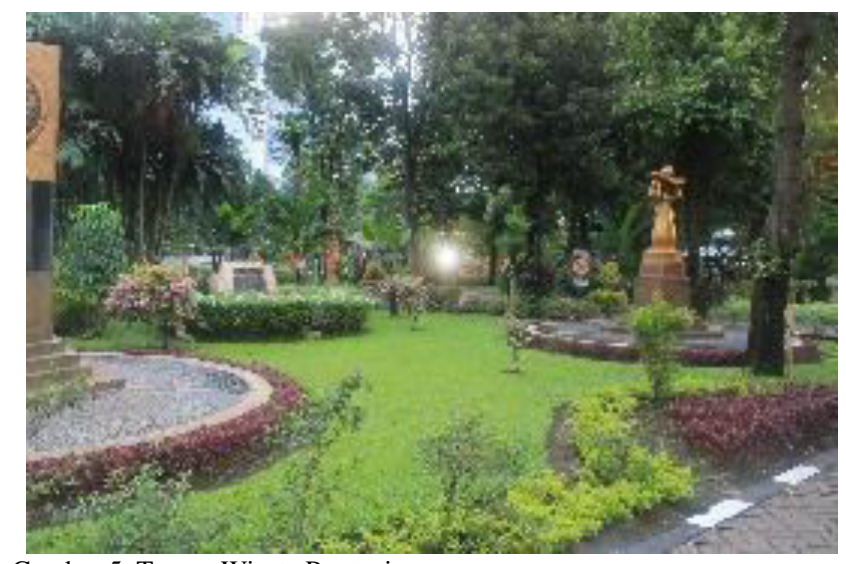

Gambar 5. Taman Wisata Prestasi.

destinasi wisata tersebut terdiri dari tahap pengenalan (introduction), pertumbuhan (growth), pendewasaan (maturity), penurunan (decline), dan/atau peremajaan (rejuvenation) [6]. Hal tersebut kemudian dijabarkan dalam tujuh tahapan siklus hidup pariwisata yang terdiri dari tahap exploration, involvement, development, consolidation, stagnation, declanation, rejuvenation ( Gambar 1).

Untuk mendapatkan gambaran evolusi di taman wisata, dalam penelitian ini identifikasi karakteristik siklus hidup dilakukan berdasarkan aspek fungsi taman [5][7] dan komponen pariwisata [8][9] sehingga didapatkan variabel pengelola, atraksi, sarana dan prasarana, aksesibilitas, upaya promosi, dan pengunjung (Tabel 1 dan 2).

\section{Metode Pengumpulan Data}

Pengumpulan data dilakukan melalui survei primer dan sekunder. Survei primer merupakan pengumpulan data yang dilakukan langsung di lapangan. Survei primer teridiri dari observasi dan wawancanar. Observasi merupakan pengamatan dengan menggunakan pedoman amatan. Sedangkan wawancara merupakan komunikasi personal yang dilakukan dengan pihak pengelola taman wisata dan wisatatawan. Pengelola memberikan keterangan mengenai ketersediaan fungsi taman komponen pariwisata sedangakan wisatawan memberikan keterangan kualitas dari komponen pariwisata yang tersedia

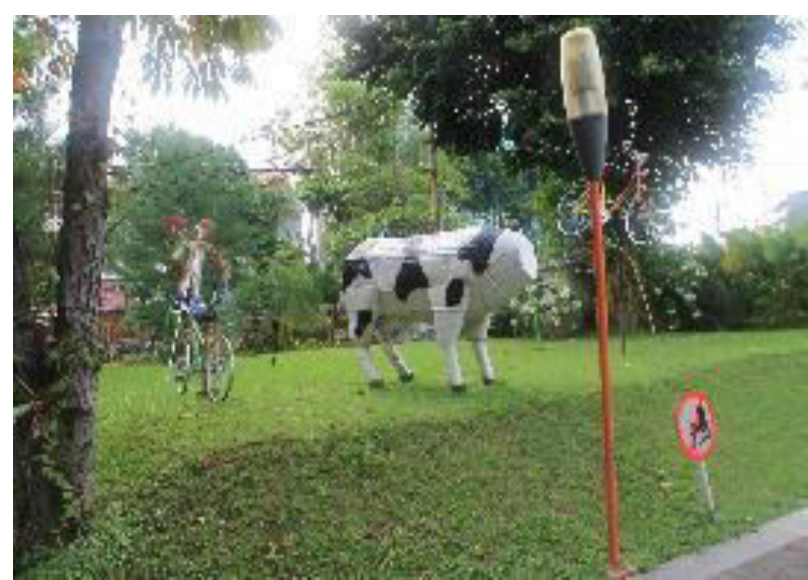

Gambar 6. Taman Wisata Ekspresi.

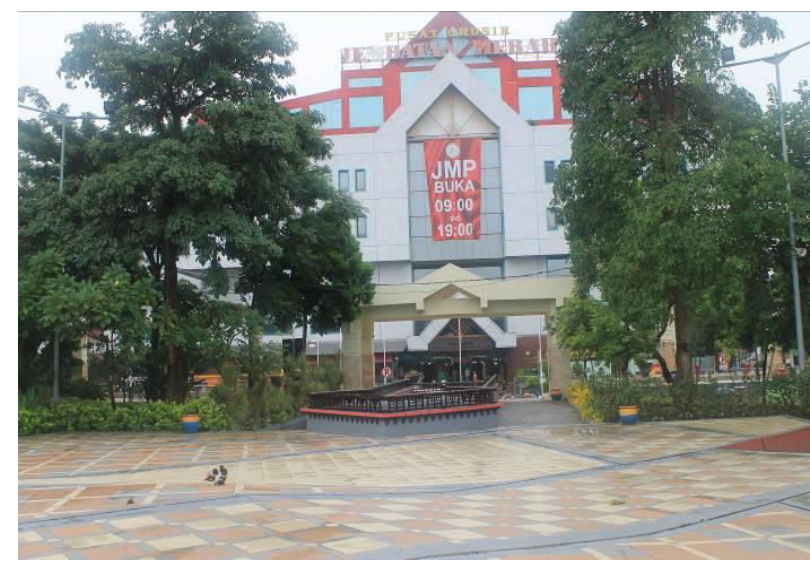

Gambar 7. Taman Wisata Jayengrono.

Sedangkan survei sekunder merupakan pengeumpulan data yang tidak dilakukan secara langsung di lapangan. Teridiri dari survei instanstional dan literatur. Survei instansional adalah pengumpulan data-data taman wisata dari instansi pengelola, sedangkan survei literatur adalah pengumpulan data berdasarkan dokumen-dokumen yang ada.

\section{Metode dan Teknik Analisis}

Dalam mengidentifikasi karakteristik taman wisata kalimas dilakukan analisis deskriptif kualitatif yang membandingkan hasil observasi, wawancara pengelola, dan penyebaran kuisioner ke wisatawan dengan variabel-variabel dalam siklus hidup pariwisata. Hasil observasi dan wawancara pengelola memberikan data mengenai ketersedian variabel yang terdapat di taman wisata kalimas. Sedangkan kuisioner wisatawan memberikan data berupa kondisi setiap variabel berdasarkan kriteria tahapan siklus hidup pariwisata. Melalui perbandingan tersebut kemudian didapatkan kesimpulan mengenai karakteristik variabel siklus hidup pariwisata di setiap taman wisata kalimas.

\section{HASIL DAN DISKUSI}

Penelitian ini dilakukan pada taman wisata di bantaran sungai kalimas yang termasuk taman hasil revitalisasi revitalisasi [2] dan menjadi objek wisata kota [3]. Taman tersebut diantaranya 


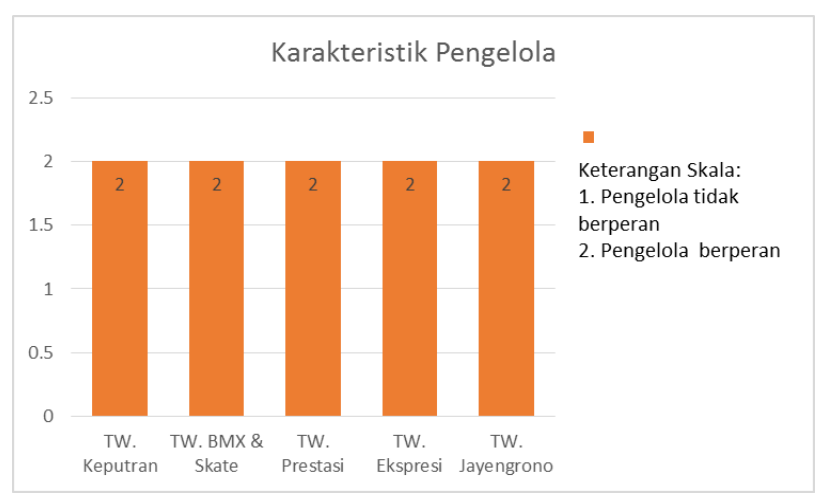

Gambar 8. Diagram Perbandingan Karakteristik Pengelola Antar Taman Wisata di Kalimas.

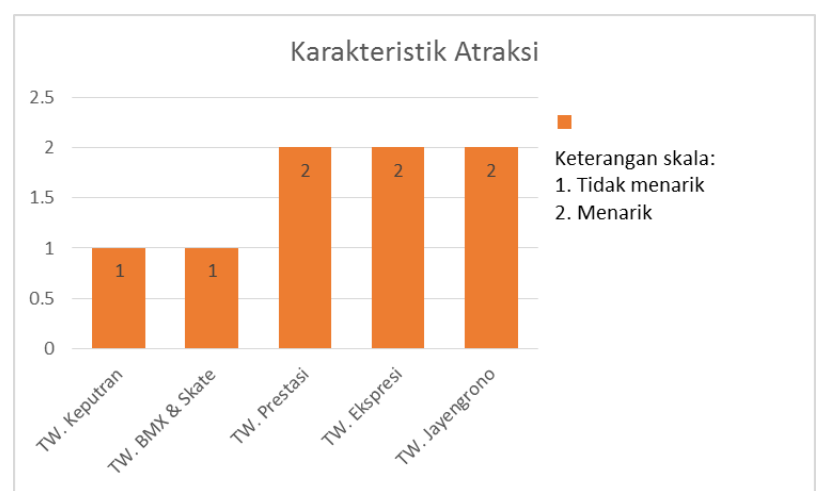

Gambar 9. Diagram Perbandingan Karakteristik Atraksi Antar Taman Wisata di Kalimas.

adalah Taman Wisata Keputran, Taman Wisata BMX \& Skate, Taman Wisata Prestasi, Taman Wisata Ekspresi, dan Taman Wisata Jayengrono (Gambar 2).

\section{A. Karakteristik Siklus Hidup Pariwisata Taman Wisata Keputran}

TW. Keputran berlokasi di dekat Pasar Keputran Surabaya, taman ini dibangun untuk menggantikan bangunan kumuh luberan dari Pasar Keputran. Berikut adalah karakteristik TW (Gambar 3). Keputran ditinjau dari segi pengelola, atraksi, fasitilas dan infrastruktur, aksesibilitas, promosi, serta pengeunjung.

Berdasarkan hasil observasi karakteristik pengelola TW. Keputran dikelola oleh Dinas Kebersihan dan Ruang Terbuka Hijau (DKRTH) Kota Surabaya. Pengelola menambahkan bahwa TW. Keputran dikelola oleh DKRTH dan ditangani oleh UPTD Taman rekreasi bersama korlap yang perannya menata dan merawat taman. Hal ini selaras dengan pernyataan wisatawan bahwa terdapat pengelola dari pemerintah kota yang berperan merawat taman.

Untuk atraksi, hasil observasi menunjukkan bahwa karakteristik atraksi di TW. Keputran terdapat atraksi alami dan buatan. Hal ini selaras dengan pernyataan pengelola bahwa pada TW. Keputran terbangun atraksi alami dan buatan untuk memenuhi fungsi lingkungan, sosial, dan estetika pada taman. Meski demikian menurut wisatawan atraksi dirasa membosankan dan menginginkan atraksi baru.

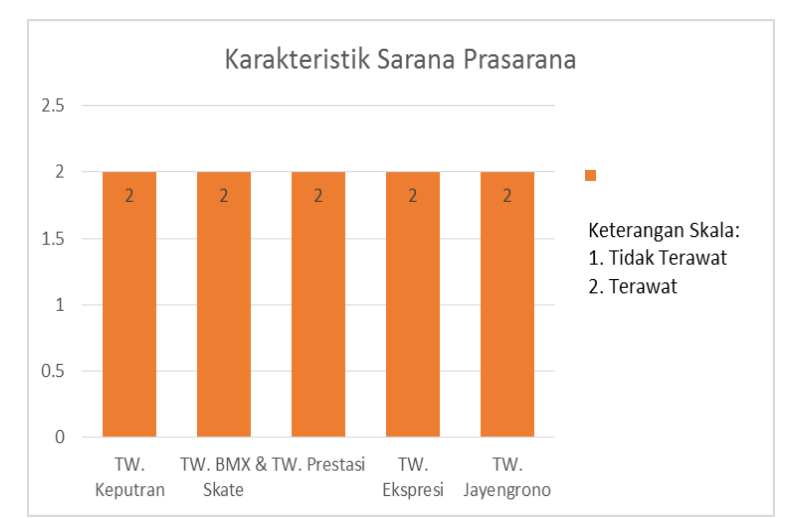

Gambar 10. Diagram Perbandingan Karakteristik Sarana Prasarana Antar Taman Wisata di Kalimas.

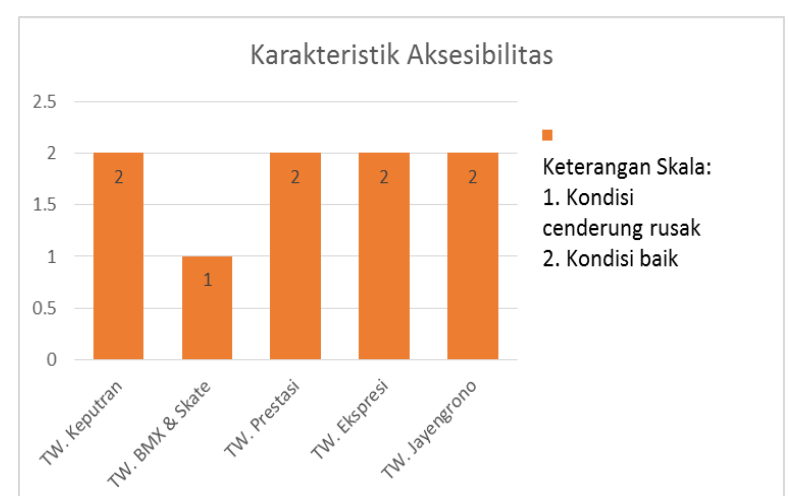

Gambar 11. Diagram Perbandingan Karakteristik Aksesibilitas Antar Taman Wisata di Kalimas.

Disamping itu hasil observasi dan pernyataan pengelola mengenai sarana dan prasarana menyatakan bahwa karakteristik sarana di TW. Keputran yang tersedia terdiri dari sarana rekreasi serta sarana sanitasi portabel dengan prasarana berupa listrik, drainase, dan persampahan. Wisatawan menyatakan kondisi sarna dan prasarana terawat, tidak ada dampak negatif, namun perlu peremajaan pada sarana rekreasi karena tidak menarik

Untuk aksesibilitas, hasil observasi dan pernyataan pengelola menunjukkan bahwa karakteristik akses pada TW. Keputran telah terbanugn jalan aspal, tersedia tempat parkir roda 2 dan 4 , serta adanya transportasi umum. Menurut wisatawan akses TW. Keputran terawat dan memadai.

Upaya promosi berdasarakan hasil observasi menunjukkan bahwa karakteristik promosi TW. Keputran tidak ditemukannya upaya promosi dari pihak pengelola, namun pengelola menyatakan upaya promosi disebarkan melalui leaflat dan situs resmi DKRTH Kota Surabaya. Meski demikian wisatawan tidak pernah mengetahui upaya promosi dari pengelola.

Sedangkan dari segi pengunjung berdasarkan hasil observasi menunjukkan bahwa karakteristik pengunjung di TW. Keputran masih memanfaatkan sarana prasarana yang ada. Meski demikian menurut pengelola trend jumlah kunjungan wisatawan meningkat namun tidak signifikan dengan hari kunjungan paling ramai cenderung senin-sabtu. Wisatawan menegaskan bahwa kunjungan ke TW. Keputran dilakukan sembari menunggu keluarga yang sedang berbelanja di pasar keputran. 


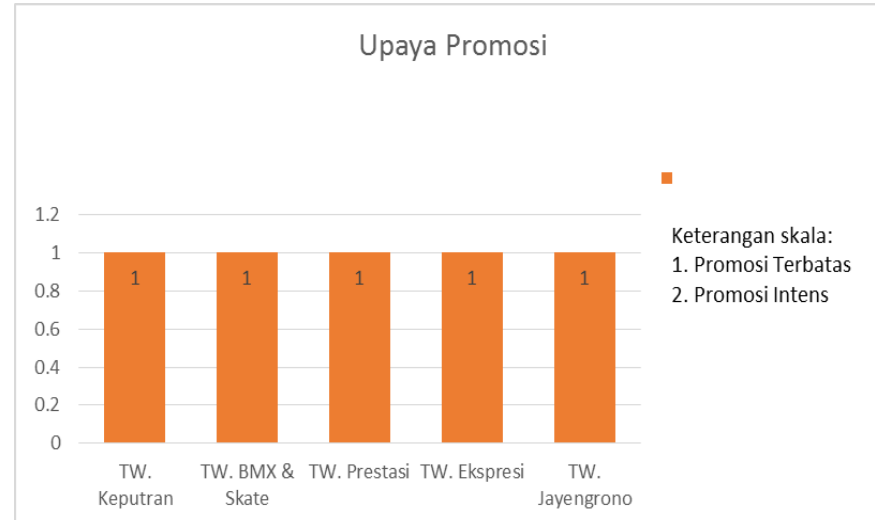

Gambar 12. Diagram Perbandingan Karakteristik Upaya Promosi Antar Taman Wisata di Kalimas.

\section{A. Karakteristik Siklus Hidup Pariwisata Taman Wisata BMX \& Skate}

Taman Wisata BMX \& Skate berlokasi di Jl. Pemuda belakan Delta Plaza (Gambar 4). Taman ini dibangun agar Kota Surabaya dapat melahirkan atlet-atlet BMX dan Skate Board handal berkelas nasional dan internasional. Berikut adalah karakteristik TW. BMX \& Skate ditinjau dari segi pengelola, atraksi, fasitilas dan infrastruktur, aksesibilitas, promosi, serta pengeunjung.

Berdasarkan hasil observasi karakteristik pengelola TW. BMX \& Skate dikelola oleh Dinas Kebersihan dan Ruang Terbuka Hijau (DKRTH) Kota Surabaya. Pengelola menambahkan bahwa TW. BMX \& Skate dikelola oleh DKRTH dan ditangani oleh UPTD Taman rekreasi bersama korlap yang perannya menata dan merawat taman. Hal ini selaras dengan pernyataan wisatawan bahwa terdapat pengelola dari pemerintah kota yang berperan merawat taman.

Untuk atraksi, hasil observasi menunjukkan bahwa karakteristik atraksi di TW. BMX \& Skate terdapat atraksi alami dan buatan. Hal ini selaras dengan pernyataan pengelola bahwa pada TW. BMX \& Skate terbangun atraksi alami dan buatan untuk memenuhi fungsi lingkungan, sosial, dan estetika pada taman dengan atraksi buatan yang lebih didominankan karena tema taman untuk olahraga skate. Selain itu juga terdapat atraksi event dilakukan pihak terentu untuk mengadakan acara di taman. Meski demikian menurut wisatawan atraksi dirasa membosankan dan menginginkan atraksi baru.

Disamping itu, hasil observasi dan pernyataan pengelola menyatakan bahwa karakteristik sarana di TW. BMX \& Skate yang tersedia terdiri dari sarana rekreasi, sanitasi dan ibadah dengan prasarana berupa listrik, drainase, dan persampahan. Wisatawan menyatakan kondisi sarna dan prasarana terawat, tidak ada dampak negatif, namun perlu peremajaan pada sarana rekreasi karena tidak menarik

Sedangkan hasil observasi dan pernyataan pengelola menunjukkan bahwa karakteristik akses pada TW. BMX \& Skate telah terbangun jalan utama dan alternatif yang teraspal, tersedia tempat parkir roda 2 dan 4, serta adanya transportasi umum. Jalan alternatif dilewati melalui tempat parkir Delta Plaza, sedangkan jalan utama dilewati melalui gang di jalan pemuda. Menurut wisatawan akses alternatif TW. BMX \&

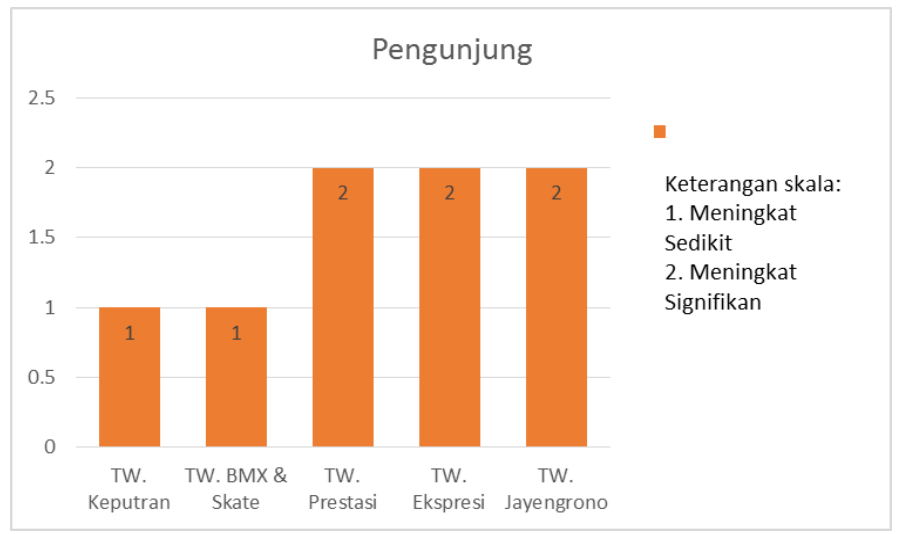

Gambar 13. Diagram Perbandingan Karakteristik Pengunjung Antar Taman Wisata di Kalimas.

Skate terawat dan memadai, namun akses utama dirasa terlalu sempit dan banyak kerusakan.

Upaya promosi berdasarkan hasil observasi menunjukkan bahwa karakteristik promosi TW. BMX \& Skate tidak ditemukannya upaya promosi dari pihak pengelola, namun pengelola menyatakan upaya promosi disebarkan melalui leaflat dan situs resmi DKRTH Kota Surabaya. Meski demikian wisatawan tidak pernah mengetahui upaya promosi dari pengelola.

Sedangkan, hasil observasi menunjukkan bahwa karakteristik pengunjung di TW. BMX \& Skate masih memanfaatkan sarana prasarana yang ada. Meski demikian menurut pengelola trend jumlah kunjungan wisatawan meningkat namun tidak signifikan dengan hari kunjungan paling ramai cenderung akhir pekan. Wisatawan menegaskan bahwa kunjungan ke TW. Keputran dilakukan setidaknya 4-8 kali dalam sebulan.

\section{B. Karakteristik Siklus Hidup Pariwisata Taman Wisata Presttasi}

Taman Wisata Prestasi berlokasi di Jalan Ketabang Kali Surabaya. Taman ini dibangun untuk untuk mengenang penghargaan yang telah diraih Kota Surabaya melalui pembangunan replika penghargaan. Berikut adalah karakteristik TW. Prestasi ditinjau dari segi pengelola, atraksi, fasitilas dan infrastruktur, aksesibilitas, promosi, serta pengeunjung (Gambar 5).

Berdasarkan hasil observasi karakteristik pengelola TW. Prestasi dikelola oleh Dinas Kebersihan dan Ruang Terbuka Hijau (DKRTH) Kota Surabaya. Pengelola menambahkan bahwa TW. Prestasi dikelola oleh DKRTH dan ditangani oleh UPTD Taman rekreasi bersama korlap yang perannya menata dan merawat taman. Hal ini selaras dengan pernyataan wisatawan bahwa terdapat pengelola dari pemerintah kota yang berperan merawat taman.

Untuk atraksi hasil observasi dan pernyataaan pengelola menunjukkan bahwa karakteristik terbangun atraksi alami dan buatan untuk memenuhi fungsi lingkungan, sosial, dan estetika pada taman dengan atraksi alami yang lebih diutamakan. Selain itu juga sering terdapat atraksi event dilakukan pihak terentu untuk mengadakan acara di taman. Wisatawan menyatakan atraksi dirasa menarik, dan tidak perlu adanya peremajaan.

Sedangakn hasil observasi dan pernyataan pengelola mengenai sarana dan prasarana menyatakan bahwa karakteristik 
sarana di TW. Prestasi terdiri dari sarana rekreasi, sanitasi, ibadah, dan penjualan dengan prasarana berupa listrik, drainase, dan persampahan. Wisatawan menyatakan kondisi sarna dan prasarana terawat, tidak ada dampak negatif, dan tidak perlu peremajaan.

Disamping itu hasil observasi dan pernyataan pengelola menunjukkan bahwa karakteristik akses pada TW. Prestasi telah terbangun jalan aspal, tersedia tempat parkir roda 2 dan 4 , namun tidak tersedia transportasi umum. Menurut wisatawan akses TW. prestasi terawat dan memadai.

Upaya promosi berdasarkan hasil observasi menunjukkan bahwa karakteristik promosi TW. Prestasu tidak ditemukannya upaya promosi dari pihak pengelola, namun pengelola menyatakan upaya promosi disebarkan melalui leaflat dan situs resmi DKRTH Kota Surabaya. Meski demikian wisatawan tidak pernah mengetahui upaya promosi dari pengelola.

Sedangkan hasil observasi mengenai pengunjung menunjukkan bahwa karakteristik pengunjung di TW. Prestasi masih memanfaatkan sarana prasarana yang ada. Menurut pengelola trend jumlah kunjungan wisatawan meningkat signifikan dengan hari kunjungan paling ramai cenderung akhir pekan. Wisatawan menegaskan bahwa kunjungan ke TW. Prestasi dilakukan setidaknya 4 kali dalam sebulan.

\section{Karakteristik Siklus Hidup Pariwisata Taman Wisata Eskpresi}

Taman Wisata Ekspresi berlokasi di Jalan Genteng Kali Surabaya. Taman ini dibangun untuk tempat mengekspresikan karya seni. Berikut adalah karakteristik TW. Ekspresi ditinjau dari segi pengelola, atraksi, fasitilas dan infrastruktur, aksesibilitas, promosi, serta pengunjung (Gambar 6).

Berdasarkan hasil observasi karakteristik pengelola TW. Ekspresi dikelola oleh Dinas Kebersihan dan Ruang Terbuka Hijau (DKRTH) Kota Surabaya. Pengelola menambahkan bahwa TW. Ekspresi dikelola oleh DKRTH dan ditangani oleh UPTD Taman rekreasi bersama korlap yang perannya menata dan merawat taman. Hal ini selaras dengan pernyataan wisatawan bahwa terdapat pengelola dari pemerintah kota yang berperan merawat taman.

Untuk atraksi hasil observasi dan pernyataaan pengelola menunjukkan bahwa karakteristik atraksi TW. Ekspresi terbangun atraksi alami dan buatan untuk memenuhi fungsi lingkungan, sosial, dan estetika pada taman dengan atraksi alami yang lebih diutamakan. Selain itu juga sering terdapat atraksi event berupa acara kesenian yang dadakan pihak terentu. Wisatawan menyatakan atraksi dirasa menarik, dan tidak perlu adanya peremajaan.

Sedangkan hasil observasi dan pernyataan pengelola mengenai sarana dan prasarana menyatakan bahwa karakteristik sarana di TW. Ekspresi terdiri dari sarana rekreasi dan sanitasi dengan prasarana berupa listrik, drainase, dan persampahan. Wisatawan menyatakan kondisi sarna dan prasarana terawat, tidak ada dampak negatif, dan tidak perlu peremajaan.

Disamping itu hasil observasi dan pernyataan pengelola mengenai aksesibilitas menunjukkan bahwa karakteristik akses pada TW. Ekspresi telah terbangun jalan aspal, tersedia tempat parkir roda 2 di dalam taman dan roda 4 di tepi jalan, serta tersedia transportasi umum. Menurut wisatawan akses TW. prestasi terawat dan memadai
Upaya promosia berdasarkan hasil observasi menunjukkan bahwa karakteristik promosi TW. BMX \& Skate tidak ditemukannya upaya promosi dari pihak pengelola, namun pengelola menyatakan upaya promosi disebarkan melalui leaflat dan situs resmi DKRTH Kota Surabaya. Meski demikian wisatawan tidak pernah mengetahui upaya promosi dari pengelola.

Sedangkan dari segi pengunjung hasil observasi menunjukkan bahwa karakteristik pengunjung di TW. Ekspresi masih memanfaatkan sarana prasarana yang ada. Menurut Pengelola Trend jumlah kunjungan wisatawan masih meningkat signifikan dengan hari kunjungan paling ramai cenderung akhir pekan. Wisatawan menegaskan bahwa kunjungan ke TW. Prestasi dilakukan setidaknya 4 kali dalam sebulan.

\section{Karakteristik Siklus Hidup Pariwisata Taman Wisata Jayenrono}

Taman Wisata Jayengrono berlokasi di kawasan Jembatan Merah Surabaya. taman ini merupakan peninggalan sejak abab ke XIX. Saat ini TW. Jayengrono digunakan untuk mengenang peristiwa sejarah-sejarah yang pernah terjadi di Surabaya khususnya di sekitaran Jembatan Merah. Berikut adalah karakteristik TW. Jayengrono ditinjau dari segi pengelola, atraksi, fasitilas dan infrastruktur, aksesibilitas, promosi, serta pengeunjung (Gambar 7).

Berdasarkan hasil observasi karakteristik pengelola TW. Jayengrono dikelola oleh Dinas Kebersihan dan Ruang Terbuka Hijau (DKRTH) Kota Surabaya. Pengelola menambahkan bahwa TW. Jayengrono dikelola oleh DKRTH dan ditangani oleh UPTD Taman rekreasi bersama korlap yang perannya menata dan merawat taman. Hal ini selaras dengan pernyataan wisatawan bahwa terdapat pengelola dari pemerintah kota yang berperan merawat taman

Untuk atraksi, hasil observasi dan pernyataaan pengelola menunjukkan bahwa karakteristik atraksi TW. Jayengrono terbangun atraksi alami dan buatan untuk memenuhi fungsi lingkungan, sosial, dan estetika pada taman dengan atraksi alami yang lebih diutamakan. Selain itu juga sering terdapat atraksi event berupa acara pagelaran budaya dari Dinas Pariwisata dan Kebudayaan Surabaya setiap minggunya. Wisatawan menyatakan atraksi dirasa menarik, dan tidak perlu adanya peremajaan.

Dismaping itu, hasil observasi dan pernyataan pengelola mengenai sarana dan prasarana menyatakan bahwa karakteristik sarana di TW. Jayengrono terdiri dari sarana rekreasi, sanitasi, penjualan (melalui JMP Mall) dengan prasarana berupa listrik, drainase, dan persampahan. Wisatawan menyatakan kondisi sarna dan prasarana terawat, tidak ada dampak negatif, dan tidak perlu peremajaan.

Sedangkan hasil observasi dan pernyataan pengelola mengenai aksesibilitas menunjukkan bahwa karakteristik akses pada TW. Jayengrono telah terbangun jalan teraspal, tersedia tempat parkir roda 2 dan 4 di JMP Mall, serta adanya transportasi umum karena dekat dengan terminal. Menurut wisatawan akses TW. JAyengrono terawat dan memadai

Upaya promosi berdasarkan hasil observasi menunjukkan bahwa karakteristik promosi TW. Jayengrono tidak ditemukannya upaya promosi dari pihak pengelola, namun pengelola menyatakan upaya promosi disebarkan melalui leaflat 
dan situs resmi DKRTH Kota Surabaya. Meski demikian wisatawan tidak pernah mengetahui upaya promosi dari pengelola.

Sedangkan hasil observasi mengani pengunjung menunjukkan bahwa karakteristik pengunjung di TW. Jayengrono masih memanfaatkan sarana prasarana yang ada. Menurut Pengelola Trend jumlah kunjungan wisatawan masih meningkat signifikan dengan hari kunjungan paling ramai cenderung akhir pekan karena ada event. Wisatawan menegaskan bahwa kunjungan ke TW. Jayengrono dilakukan setidaknya 4 kali dalam sebulan.

Berdasarkan hasil identifikasi karakteristik tiap taman di atas, apabila dibandingkan karakteristik tiap taman maka didapatkan bahwa meski seluruh taman memiliki pengelola resmi yang berperan mengelola taman, namun TW. Keputran dan TW. BMX memiliki atarksi yang tidak menarik sedangkan TW. Prestasi, TW. Ekspresi, dan TW. Jayengrono masih memiliki atraksi yang menarik. Meski demikian, karakteristik sarana dan prasana di setiap taman memiliki kondisi yang terawat. Diagram perbandingan karakteristik pengelola taman wisata dapat dilihat pada Gambar 8. Diagram perbandingan karakteristik setiap taman dari segi atraksi Gambar 9. Dan Diagram sarana prasarana dapat dilihat pada Gambar 10.

Sedangkan dari segi aksesibilitas secara keseluruhan memiliki kondisi yang baik, hanya TW. BMX \& Skate yang memiliki kondisi akses utama kondisi cenderung rusak. Disisi lain upaya promosi untuk setiap taman memiliki upaya yang hanya terbatas, tidak ada taman yang melakukan upaya promosi secara intens. Meski demikian tak rata-rata trend kunjungan wisatawan di setiap taman wisata meningkat signifikan, hanya pada TW. Keputran dan TW. BMX \& Skate yang memiliki jumlah kunjungan yang hanya meningkat sedikit. Diagram perbandingan karakteristik akssisibilitas antar taman dapat dilihat pada Gambar 11. Untuk diagram perbandingan upaya promosi dapat dilihat pada dilihat pada Gambar 12. Sedangkan diagram perbandingan karakteristik pengunjung dapat dilihat pada Gambar 13.

\section{KESIMPULAN}

Pada hasil penelitian ini identifikasi karakteristik berdasarkan setiap varibel siklus hidup pariwisata di Taman Wisata BMX \& Skate, maka dapat diambil kesimpulan bahwa:

1. Atraksi pada taman wisata kalimas secara keseluruhan terbangun atraksi alami (lingkungan dan estetika) serta buatan. Pada semua taman kalimas atraksi alami lebih ditonjolkan daripada buatan kecuali pada TW. BMX dan Skate atraksi buatan lebih ditonjolkan. Pada TW. Keputran dan BMX \& skate atraksi dianggap membosankan dan butuh peremajaan, sedangkan pada
TW. Prestasi, Ekspresi, dan Jayengrono atarksi masih menarik.

2. Jumlah pengunjung pada taman wisata di kalimas ada yang meningkat sedikit dan ada yang meningkat signifikan. Pada TW. Keputran dan BMX \& Skate jumlah kunjungan hanya meningkat sedikit, sedangkan pada taman wisata Prestasi, Ekspresi, dan Jayengrono meningkat signifikan

3. Pengelola di seluruh taman wisata kalimas adalah DKRTH Kota Surabaya yang diturunkan pada UPTD taman Rekreasi dengan korlap dan satgas lapangan. Peran DKRTH dan UPTD taman rekreasi yakni menata dan merawat taman wisata

4. Fasilitas yang tersedia di seluruh taman rata-rata adalah sarana rekreasi dan sanitasi dengan kondisi terawat. Hanya pada TW. Prestasi terdapat sarana rekreasi, sanitasi, ibadah, dan penjualan. Sedangkan prasarana di semua taman wisata sudah terlayani listrik, air bersih, drainase, dan persampahan. Sarana dan prasaran di seluruh taman wisata tidak memberi dampak negatif baik pada ekonomi, sosial, dan lingkungan sekitar.

5. Aksesibilitas pada taman wisata di kalimas rata-rata sudah terbangun jalan umum dengan kondisi baik. Hanya pada TW. BMX \& skate jalan utama dirasa terlalu sempit dan ada kerusakan. Sedangkan transportasi umum sudah tersedia di setiap taman wisata kecuali TW. Prestasi.

6. Promosi di setiap taman wisata memiliki karakteristik yang sama yakni hanya dengan memanfaatkan leaflat, dan situs resmi DKRTH Surabaya.

\section{DAFTAR PUSTAKA}

[1] Badan Perencana Pembangungan Kota Surabaya, "Rencana Tata Ruang Wilayah Kota Surabaya tahun 2014-2034,” Surabaya, 2014.

[2] Badan Perencana Pembangunan Kota Surabaya, "Rencana Penataan dan Revitalisasi Sungai Kalimas tahun 2006," Surabaya, 2006.

[3] Dinas Kebudayaan dan Pariwisata Kota Surabaya, "Draft Rencana Induk Pariwisata Kota Surabaya tahun 2017-2032," Surabaya.

[4] S. Bakti, "Implementasi Revitalisasi Bantaran Sungai Kalimas Pada Taman Keputran Di Kota Surabaya,” J. Undip, vol. 3, no. 6, 2015.

[5] P. Sasongko, "Kajian Perubahan Fungsi Taman Kota di Semarang," Semarang, 2002.

[6] K. Pitana, I., \& Diarta, Pengantar Ilmu Pariwisata. Yogyakarta: Andi, 2009.

[7] I. Beladdinilma, "Konsep Pengembangan Taman Kota Di Surabaya Timur," Surabaya, 2010.

[8] G. Gunardi, "Identifikasi Potensi Kawasan Wisata Kali Pasir, Kota Tangerang," J. Planesa, vol. 1, no. 1, pp. 28-35, 2010.

[9] H. Nursinggih, "Kajian Komponen Penawaran dan Permintaan Wisata Sebagai Penunjang Kepariwisataan Budaya Kota Cirebon," Semarang, 2001. 